\title{
Huntington's disease and dementia: from structural changes to
} clinical issues

\author{
Andreas Michos*1, Magdalini Krommyda ${ }^{1}$, Panagiotis Beredimas ${ }^{1}$ and \\ Theodoros Nikolaou ${ }^{2}$
}

\author{
Address: ${ }^{1}$ Neurology department, Petra-Olympou Psychiatric Hospital, Katerini, Greece and ${ }^{2}$ Psychiatric department, Petra-Olympou Psychiatric \\ Hospital, Katerini, Greece \\ * Corresponding author
}

\author{
from International Society on Brain and Behaviour: 3rd International Congress on Brain and Behaviour \\ Thessaloniki, Greece. 28 November - 2 December 2007 \\ Published: 17 April 2008 \\ Annals of General Psychiatry 2008, 7(Suppl I):S328 doi:I0.I I86/I744-859X-7-SI-S328
}

This abstract is available from: http://www.annals-general-psychiatry.com/content/7/SI/S328

(c) 2008 Michos et al.; licensee BioMed Central Ltd.

\section{Background}

Huntington's disease (HD) is an autosomal dominant neurodegenerative disorder, which occurs in patients with a mutation in the IT15 gene (huntingtin). Clinically, the disease presents itself with not only motor symptoms but also dementia. The aim of this study is to review and present all recent data, specifically those related to the neuropathology, biochemistry and diagnostic methods of dementia in HD.

\section{Materials and methods}

Recent advances in molecular and genetic research of HD, derived from articles published in journals indexed in PubMed and other Entrez medical databases are being reviewed in an effort to elucidate mechanisms of cell death in the striatum and disruption of cortical-striatal circuitry. Neurophysiological and imaging diagnostic methods are analytically described, while the utility of other rating scales, like the Unified HD Rating Scale, in the differential diagnosis between HD and other dementias is evaluated according to several clinical trials, described in various biomedical literature citations.

\section{Results}

HD causes widespread CNS changes and systemic abnormalities, while cell death mechanisms involve variable processes, such as mitochondrial abnormalities, excitotoxicity, neuroinflammation and abnormal protein degradation [1]. Genetic testing, consideration of the inherited disease risk, clinical assessment, neuroimaging techniques, cognitive and psychological rating scales contribute significantly not only to HD diagnosis, but also prognosis [2].

\section{Conclusions}

HD is a devastating neurological condition of long duration. Many factors likely contribute to neuron death and dysfunction, making the systematic address of its pathology difficult. The first signs and symptoms are often present before impairments reach a point where the neurologic disease manifests itself, but usually are subtle and remain unnoticed $[3,4]$. For this reason, clinical rating should focus not only on motor difficulties, but also on the neuropsychological performance of patients as a whole, aiming to detect different types of impairment within this neuropsychiatric disorder. Further research in relation to the understanding of the mechanisms involved in the memory and cognitive impairment of HD and enrichment of the diagnostic tools of all cognitive and emotional declines early in the disease process can have implications for prognostic assessment of persons at risk and eventually assist with early interventions.

\section{References}

I. Perutz MF, Windle AH: Cause of neural death in neurodegenerative diseases attributable to expansion of glutamine repeats. Nature 200I, 4I 2: I43-4.

2. Paulsen JS, Ready RE, Hamilton JM, Mega MS, Cummings JL: Neuropsychiatric aspects of Huntington's disease. I Neurol Neurosurg Psychiatry 2001, 71 : 310-314. 
3. Nakamura K., Aminoff MJ.: Huntington's disease: clinical characteristics, pathogenesis and therapies. Drugs Today (Barc) 2007, 43(2):97-II6.

4. Huntington Disease Center Baylor College of Medicine Department of Neurology, Houston, 77030, USA [http:// www.bcm.edu/neurology/struct/huntington/hd.html]

Publish with Bio Med Central and every scientist can read your work free of charge

"BioMed Central will be the most significant development for disseminating the results of biomedical research in our lifetime. " Sir Paul Nurse, Cancer Research UK

Your research papers will be:

- available free of charge to the entire biomedical community

- peer reviewed and published immediately upon acceptance

- cited in PubMed and archived on PubMed Central

- yours - you keep the copyright

Submit your manuscript here:

http://www.biomedcentral.com/info/publishing_adv.asp 